ISSN: 2224-0616

Int. J. Agril. Res. Innov. Tech. 10(1): 28-34, June 2020

DOI: https://doi.org/10.3329/ijarit.v10i1.48091

\section{OPEN 2 ACCESS}

Available online at https://ijarit.webs.com https://www.banglajol.info/index.php/IJARIT

\title{
Growth performance, gut health, carcass yield traits and profitability of broiler chicken raised on compound diet supplemented with probiotics
}

\author{
M.A. Hossain ${ }^{1 *}$, S. Dev¹ , I. Jahan² and M.M. Hossain ${ }^{3}$ \\ Received 4 April 2020, Revised 18 April 2020, Accepted 20 June 2020, Published online 30 June 2020
}

\begin{abstract}
A B S T R A C T
The present study was conducted to investigate the effects of probiotic on growth performance, gut health, viability, carcass yield traits and cost benefit analyses etc., of broiler chicken from d1-28 days. A total of 192 day-old broiler chicks (Ross 308) was assigned into four dietary treatment groups, i.e. $\mathrm{D}_{1}$ (Control), $\mathrm{D}_{2}$ (Poultry Starsol), $\mathrm{D}_{3}$ (Avilac plus) and D4 (Avibac), and each treatment replicated six times with eight birds per replicate in a completely randomized design. The chicks were raised in battery cages all the trial period. Ready-made starter diet (crumble) was fed the chicks up to 14 days, after that, grower (pellet) diet fed the broiler from d 15 to 28 days. The water treated with probiotics at the rate of $1.0 \mathrm{~g} \mathrm{~L}^{-1}$ (Poultry Starsol), $1.0 \mathrm{ml} \mathrm{L}^{-1}$ (Avilac plus) and $1.0 \mathrm{~g} \mathrm{~L}^{-1}$ (Avibac) in $\mathrm{D}_{2}, \mathrm{D}_{3}$ and $\mathrm{D}_{4}$ treatment groups, respectively, and supplied the birds ad libitum entire the trial period. Data on feed intake (FI), body weight gain (BWG), feed conversion ratio (FCR) and livability (\%) were collected. Apart from this, caecal digesta sample was taken on 28 days to determine the gut microflora population, i.e. total viable count (TVC) and total lactobacilli count (TLC) of broilers. Carcass characteristics (dressing \%, blood weight, drumstick weight, thigh weight, breast weight \%) and cost benefit were also calculated on the last day of trial period to assess the different meat cuts and the profitability of broiler. The data revealed that FI, viability (\%), TVC and TLC of broilers had no difference $(\mathrm{P}>0.05)$ between treatment on 28d. Except for first week, BWG was improved significantly $(\mathrm{P}<0.05)$ in the birds fed probiotics during d1-21 and d1-28, respectively. Superior FCR values $(1.30,1.34)$ were observed in the broilers of probiotics supplemented groups from d1-28 days of age. The results of carcass traits were influenced significantly $(\mathrm{P}<0.05)$ by dietary treatment. The percentage of breast weight, thigh weight, dressing yield, drumstick weight and blood weight was increased $(\mathrm{P}<0.05)$ in the supplemental group compared to control. Higher $(\mathrm{P}<0.01)$ net profit was observed in the birds of probiotics supplemented group than that of control group. It can be concluded that broiler responded positively as a result of probiotics supplementation in water, and can be raised profitably under farming condition with low cost.
\end{abstract}

Keywords: Growth, Microflora, Carcass trait, Probiotics, Viability, Profitability, Broiler chicken.

${ }^{1}$ Department of Dairy \& Poultry Science, Chittagong Veterinary and Animal Sciences University, Khulshi, Chittagong-4225, Bangladesh.

${ }^{2}$ Department of Botany, University of Chittagong, Chittagong-4331, Bangladesh.

${ }^{3}$ Department of Livestock Services, OTI, Savar, Dhaka, Bangladesh.

*Corresponding author's email: mahossain@cvasu.ac.bd (M.A. Hossain)

Cite this article as: Hossain, M.A., Dev, S., Jahan, I. and Hossain, M.M. 2020. Growth performance, gut health, carcass yield traits and profitability of broiler chicken raised on compound diets supplemented with probiotics. Int. J. Agril. Res. Innov. Tech. 10(1): 28-34. https://doi.org/10.3329/ijarit.v10i1.48091

\section{Introduction}

Broiler chicken producing is now growing industry across the globe. The main goal of broiler production is to meet the huge protein gap of the consumer world. Currently, the broiler industry is considered as the highest sources of animal protein production, which is being doubled day by day more rapidly than those of other food producing animal industries (Ohimain and Ofongo, 2012).

The main goal of poultry integrators is to achieve optimum production with low investment. This trend is intensifying and putting force over the poultry geneticists and nutritionists to explore alternative policies for profitable poultry production. Different feeding strategies such as reduction of specific nutrient content with addition of various supplements in poultry diets have been potential to increase the productive performance and reduce feed cost. Now poultry nutritionists and researchers are looking for alternative feeds or supplements to enhance poultry performance due to ban of animal byproducts and indiscriminate uses of antibiotics in

International Journal of Agricultural Research Innovation \& Technology An open access article under (C) () 
animal nutrition by European Union (CEC, 2000; Adil et al., 2010). One such alternative could be supplementing probiotics in poultry diet for boosting poultry production.

Unfortunately, indiscriminate and overuse of antibiotics in animal production have promoted the growth of resistant bacteria. Now it has been a great challenge and burning issues for the farmers how to control these pathogenic organisms without using antibiotics (Ohimain and Ofongo, 2012; Wallace et al., 2010). The loss of productivity and increase in mortality of poultry industry most likely due to pathogenic infection (Patterson and Burkholder, 2003).

Lately, there has been an increase in the use of probiotics as feed additives, because of the fear of antibiotic resistance and the implications for human health. Probiotics and other feed additives have been used in poultry diets and drinking water for decades and seem to elicit positive responses in growth performance. The removal of antibiotics growth stimulator from the feed is one of the major challenges for the industrial poultry and domestic animals. Many additives can be alternatively used instead of antibiotics in poultry feed, which include probiotics, prebiotics and organic acids (Dibner and Richards, 2005; Cakir et al., 2008).

Given the growing concerns of bacterial resistance against antibiotics and the incidence of some cancers and disruption of food chains, European Union (EU) in 2006, the use of all antibiotics in the feed of poultry and other farm animals has already been banned. Therefore, adoption of new strategies to reduce the risk of bacterial resistance to antibiotics through food pyramid from farm livestock to humans are crying need now-a-days. Due to the difficulties ahead, there is a need to identify new alternatives to antibiotics. Probiotics or other feed additives might have the potential to replace the antibiotics as growth promoters in poultry diet (Dibner and Richards, 2005; Gunal et al., 2006; Cakir et al., 2008). However, many studies have been conducted to evaluate the effect of probiotics on growth responses of poultry species in the world. The inconclusive results, application of different dosages, different origin of manufacturing company etc., warrant futher study to assess the effect of probiotics on the productive peroformance of broiler. Broiler farmer can be benefitted from using the probiotics in the diet instead of using antibiotics for reduction of feed cost and profitable broiler production. Therefore, the present study was undertaken to evaluate the efficiency of various probiotics supplements in poultry to assess the productivity of broiler chicken.

\section{Materials and Methods}

A total of 192 (Ross 308) day-old broiler chicks was procured from a local commercial hatchery to conduct this experiment from d 1 to 28 days. The chicks $(46.33 \pm 0.01 \mathrm{~g} / \mathrm{b})$ were weighed on receipt, and then randomly assigned into four treatment groups, i.e $\mathrm{D}_{1}, \mathrm{D}_{2}, \mathrm{D}_{3}$ and $\mathrm{D}_{4}$. Each treatment had six replicates with eight birds per replicate in a completely randomized design (Table 1). All the chicks were allotted into 24 similar pens in a battery cage housing condition. Each pen was furnished with hanging feeder and automatic drinker to get an easy access of feed and water for the birds during the trial period. The chicks were brooded with electric bulb (100 watt) placed hanging at the middle of the each pen. For the first two days, the chicks were provided with a temperature of $33^{\circ} \mathrm{C}$. The temperature was then gradually reduced by 1 or $2^{\circ} \mathrm{C}$ every 1 or 2 days until the chicks were 19 days old at which point the temperature was maintained at $24^{\circ} \mathrm{C}$ for the rest of the trial period.

Eighteen hours of lighting and six hours darkness per day were provided throughout the trial period except for first week only, and at this period continuous lighting (23 h light: $1 \mathrm{~h}$ darkness) program was maintained for the chicks. The ready-made (crumble-pellet; C.P. Bangladesh Co. Ltd.) broiler diets (starter and grower) were procured from the local market of Chittagong, and fed the birds entire the trial period (d1-28). The broiler chicks were fed with starter diets up to 14 days, after that, grower diets were used for the remaining period (d15-28d). The probiotics i.e. Starsol, Avilac Plus, and Avibac etc. were collected from the nearby market of Chittagong. The manufacturing companies of these probiotics are Renata Ltd. (Starsol), Orion Pharma Ltd. (Avilac Plus) and Opsonin Pharma Ltd. (Avibac), respectively. The probiotics were mixed with water at the particular doses (shown below in Table 1), and this treated water was used for drinking the broilers for entire the trial period.

Table 1. Layout of experiment.

\begin{tabular}{|cccccccc|}
\hline Treatment & \multicolumn{8}{c|}{ Number of birds per replicate } & No. of bird \\
& $\mathrm{R}_{1}$ & $\mathrm{R}_{2}$ & $\mathrm{R}_{3}$ & $\mathrm{R}_{4}$ & $\mathrm{R}_{5}$ & $\mathrm{R}_{6}$ & \\
\hline $\mathrm{D}_{1}$ & 8 & 8 & 8 & 8 & 8 & 8 & 48 \\
\hline $\mathrm{D}_{2}$ & 8 & 8 & 8 & 8 & 8 & 8 & 48 \\
\hline $\mathrm{D}_{3}$ & 8 & 8 & 8 & 8 & 8 & 8 & 48 \\
\hline $\mathrm{D}_{4}$ & 8 & 8 & 8 & 8 & 8 & 8 & 48 \\
\hline Total & 32 & 32 & 32 & 32 & 32 & 32 & Grand total $=192$ \\
\hline
\end{tabular}

$D_{1}$ refers to control group without probiotics, whereas $D_{2}$ refers to probiotics $1.0 \mathrm{~g} \mathrm{~L}^{-1}$ (Starsol), $D_{3}$ indicate probiotics $1.0 \mathrm{ml} \mathrm{L}^{-1}$ (Avilac plus) and $\mathrm{D}_{4}$ denotes $1.0 \mathrm{~g} \mathrm{~L}^{-1}$ (avibac), respectively. 


\section{Data collection}

Prior to feeding, chicks were weighed and recorded at the first day of starting trial. Live weight, feed consumption and feed conversions ratio were calculated weekly. Mortality was recorded when it occurred. Data on carcass yield traits (breast weight, thigh weight, dressing yield, drumstick weight and blood weight) and cost benefit analyses were also assessed on the last day of trial. Apart from these, feed samples were collected and analyzed in the laboratory (Table 2). Besides, total viable count (TVC) and total lactobacillus count (TLC) were also determined in the laboratory from the faecal samples collected on the last day by slaughtering birds.

Table 2. Nutrient composition of compound feed (CP) supplied the broiler.

\begin{tabular}{|lcc|}
\hline Nutrient (\%) & Reported value & Analytical value \\
\hline Dry matter & 88.20 & 87.74 \\
\hline Crude protein & 21.50 & 23.05 \\
\hline Crude fiber & 5.00 & 5.73 \\
\hline Ether extract & 3.50 & 7.40 \\
\hline Ash & 6.00 & 5.65 \\
\hline Calcium & 1.00 & 1.11 \\
\hline Phosphorus & 0.50 & 0.66 \\
\hline Metabolisible Energy $\left(\mathrm{Kcal} \mathrm{kg}^{-1}\right)$ & 2950.00 & 3253.25 \\
\hline
\end{tabular}

\section{Sample analyses}

\section{Feed sample}

The collected feed samples were prepared by grinding with pestle and mortar in the laboratory. After that, the samples were sent to the laboratory for proximate analyses. The procedure for the estimation of dry matter (DM), crude protein (CP), crude fibre (CF), ether extract (EE), ash, nitrogen free extract (NFE) etc., were those of AOAC (2007). True metabolizable energy (TME) content of the taken samples was determined indirectly by using the values of $\mathrm{CF}$, $\mathrm{EE}$, and ash contents (\%) fitted to a formula suggested by Wiseman (1987). Metabolizable energy (ME) was determined indirectly on the basis of TME contents of the feed samples, assuming that TME was $8 \%$ higher than the ME, as it is reported that TME is $5-10 \%$ higher than ME (Wiseman,1987). The formula of TME is: $3951+54.4$ EE - 88.7 CF - 40.8 Ash. Calcium and phosphorus content of the feed samples were determined by atomic absorption and spectrophotometry, respectively.

Preparation of samples for bacteriological studies

Portion of cecum with their contents were obtained aseptically with a sterile scalpel and forceps. These portions were homogenized uniformly using a mortar and pestle. From the homogenized mass, one-gram portion was transferred to a sterile tube containing $9 \mathrm{ml}$ of 0.1 $\%$ peptone water. Thus, 1: 10 dilution of the sample was obtained. Later on serial dilutions of each sample in $0.1 \%$ peptone water were made as per recommendation of International Organization for Standardization (ISO, 1995).

\section{Enumeration of total viable count (TVC)}

For the determination of total bacterial counts, $0.1 \mathrm{ml}$ of each ten-fold dilution was transferred and spread on triplicate PCA or NA agar using a sterile pipette for each dilution. The diluted samples were spread as quickly as possible on the surface of the plate with a sterile glass spreader. One sterile spreader was used for each plate. The plates were then kept in an incubator at $35^{\circ} \mathrm{C}$ for 24-48 hours. Following incubation, plates exhibiting 30-300 colonies were counted. The average number of colonies in a particular dilution was multiplied by the dilution factor to obtain the total viable count. The total viable count was calculated according to ISO (1995). The results of the total bacterial count were expressed as the number of organism of colony forming units per gram ( $\mathrm{CFU} \mathrm{g^{-1 }}$ ) of crop and caecum samples.

\section{Enumeration of total lactobacillus count (TLC)}

For the determination of total lactobacillus count and the procedures of sampling, dilution and Streaking was similar to those followed in the total bacterial count. Only in case of lactobacillus count MRS agar was used. To perform MPN technique $1.0 \mathrm{ml}$ of each tenfold dilution was transferred to $9.0 \mathrm{ml}$ MacConkey broth. For each dilution five test tube, containing $9.0 \mathrm{ml}$ MacConkey broth were used. All the test tubes were incubated at $30^{\circ} \mathrm{C}$ temperature for 48 hours. Growth of the organism was confirmed by the appearance of turbidity.

\section{Statistical analyses}

All collected data were statistically analyzed using Minitab software (Minitab Version 16, 2000). The data were analyzed using one-way ANOVA with diet as factor. The significance of differences between means was determined by Fisher's least significant difference at $P \leq 0.05$. 


\section{Results}

The gross responses and livability of broiler chicken fed probiotics

The results of body weight gain (BWG), feed intake (FI) and feed conversion ratio (FCR) of broilers were presented in the Table 3. The BWG of broilers fed probiotics differed significantly between treatments entire the trial period, except for first week. Significantly highest BWG (1728.0 $\mathrm{g} / \mathrm{b}$ ) was found in the bird fed $\mathrm{D}_{3}$ group, whereas $\mathrm{D}_{1}$ being the lowest BWG $(1584.70 \mathrm{~g} / \mathrm{b})$ from $\mathrm{d} 1$ 28 . The BWG up to $21 \mathrm{~d}$ was found significantly $(\mathrm{P}<0.05)$ increased in $\mathrm{D}_{2}, \mathrm{D}_{3}$ and $\mathrm{D}_{4}$ groups of birds, and it was similar between these group. The results of FI showed no significant difference $(\mathrm{P}>0.05)$ between the treatment group from $\mathrm{d} 1$ 28 days. Numerically, birds on $\mathrm{D}_{2}$ group consumed more feed than that of other diet group on day 28d, though no difference $(\mathrm{P}>0.05)$ was observed between treatment. The FI of $\mathrm{D}_{3}$ group is $22247.7 \mathrm{O} \mathrm{g}$ followed by $2245.70,2243.70 \mathrm{~g}$, and $2251.70 \mathrm{~g}$ in $\mathrm{D}_{4}, \mathrm{D}_{2}$ and $\mathrm{D}_{1}$, respectively. The FCR data revealed that the FCR of broiler differed significantly $(\mathrm{P}<0.01)$ during last week $(28 \mathrm{~d})$ only, except for others. Improved FCR values were observed in the broiler of $\mathrm{D}_{2}, \mathrm{D}_{3}$, and $\mathrm{D}_{4}$ groups compared to those of other group $\left(D_{1}\right)$. The data on livability were presented in Fig. 1. It is evident that $95.83 \%$ livability was found in $\mathrm{D}_{2}$ group, and other groups had $100 \%$ livability. In fact, the data of viability of broilers revealed that there was no significant difference $(\mathrm{P}>0.05)$ among the treatment group.

\section{Caecal microflora of broiler chicken}

The data of gut microflora of broilers presented in Table 4. Data showed that total viable count (TVC) and total lactobacilli count (TLC) had no significant difference $(\mathrm{P}>0.05)$ between the treatment.

Table 3. Body weight gain (BWG), fed intake (FI) and FCR of broiler fed probiotic from d1- 28 days.

\begin{tabular}{|cccccccc|}
\hline & $\begin{array}{c}\text { Age } \\
\text { (days) }\end{array}$ & $\mathrm{D}_{1}$ & \multicolumn{2}{c}{ Treatment } & SEM & P-values \\
& $1-7$ & 163.33 & 167.33 & 166.33 & 165.00 & 0.750 & 0.330 \\
\cline { 2 - 8 } & $1-14$ & $377.00^{\mathrm{b}}$ & $386.67^{\mathrm{a}}$ & $390.00^{\mathrm{a}}$ & $392.67^{\mathrm{a}}$ & 1.674 & 0.047 \\
\cline { 2 - 8 } BWG (g/b) & $1-21$ & $943.00^{\mathrm{b}}$ & $957.00^{\mathrm{a}}$ & $963.67^{\mathrm{a}}$ & $969.00^{\mathrm{a}}$ & 2.480 & 0.028 \\
\cline { 2 - 9 } & $1-28$ & $1584.70^{\mathrm{c}}$ & $1671.00^{\mathrm{b}}$ & $1728.00^{\mathrm{a}}$ & $1724.70^{\mathrm{a}}$ & 7.159 & 0.010 \\
\hline & $1-7$ & 168.67 & 170.67 & 168.67 & 170.33 & 1.348 & 0.923 \\
\hline \multirow{3}{*}{ FI (g/b) } & $1-14$ & 633.00 & 629.33 & 628.67 & 629.67 & 2.520 & 0.929 \\
& $1-21$ & 1396.00 & 1376.70 & 1375.70 & 1377.70 & 4.965 & 0.458 \\
\hline & $1-28$ & 2251.70 & 2243.70 & 2247.70 & 2245.70 & 6.350 & 0.973 \\
\hline & $1-7$ & 1.03 & 1.02 & 1.01 & 1.032 & 0.008 & 0.786 \\
\hline & $1-14$ & 1.68 & 1.63 & 1.61 & 1.60 & 0.014 & 0.272 \\
\hline & $1-21$ & 1.48 & 1.44 & 1.43 & 1.42 & 0.008 & 0.111 \\
\hline & $1-28$ & $1.42^{\mathrm{a}}$ & $1.34^{\mathrm{b}}$ & $1.30^{\mathrm{b}}$ & $1.30^{\mathrm{b}}$ & 0.006 & 0.010 \\
\hline
\end{tabular}

[Data represent mean values of 8 birds per replicate groups during 1- 28 days; D refers to control diet without probiotics, whereas $D_{2}$ refers to probiotics $1.0 \mathrm{~g} \mathrm{~L}^{-1}$ (Starsol); $D_{3}$ indicates probiotics $1.0 \mathrm{ml} \mathrm{L} \mathrm{L}^{-1}$ (Avilac plus) and $D_{4}$ denotes $1.0 \mathrm{~g} \mathrm{~L}^{-1}$ (Avibac). respectively; a,b,c Means bearing uncommon superscripts within a row are significantly different at the levels shown above; SEM= Pooled standard error of means].

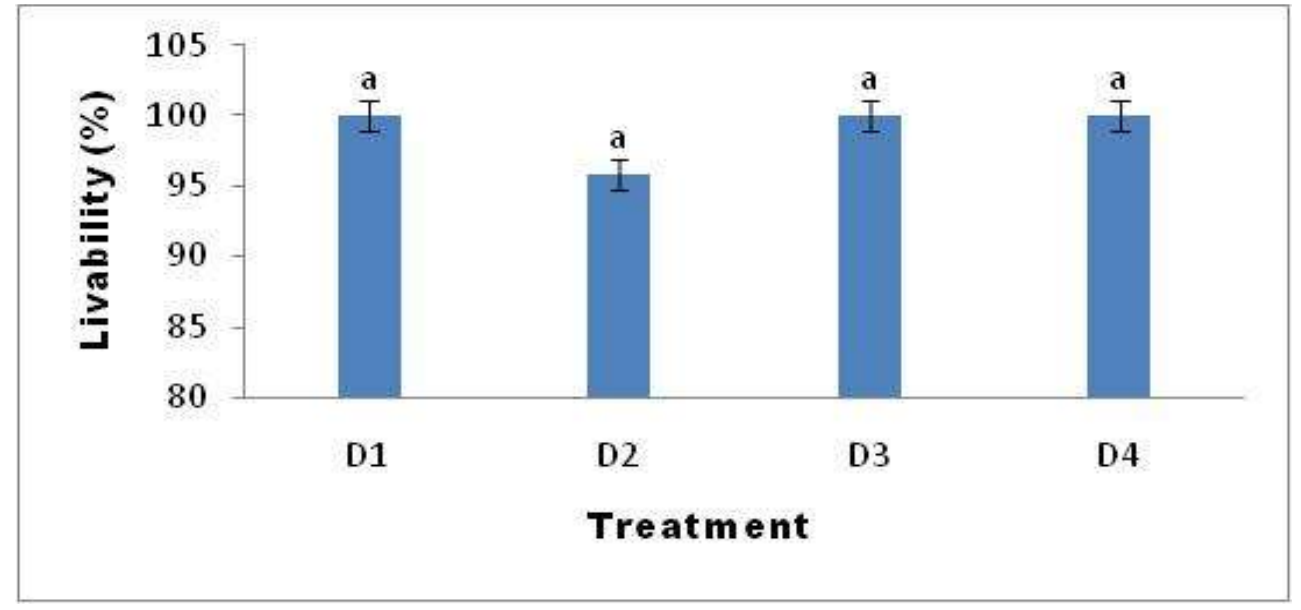

Fig. 1. Livability of broiler chickens fed probiotics from d1-d28; Bar with similar letter has no significant difference $(\mathrm{P}>0.05)$ between treatments. 
Table 4. The total viable count (TVC) and total lactobacilli count (TLC) of caecal microflora of broiler fed porbiotics on 28 days.

\begin{tabular}{|c|c|cccccc|}
\hline & $\begin{array}{c}\text { Age } \\
\text { (day) }\end{array}$ & $\mathrm{D}_{1}$ & $\mathrm{D}_{2}$ & $\mathrm{D}_{3}$ & $\mathrm{D}_{4}$ & SEM & P-values \\
\hline TVC & 28 & $11.07 \times 10^{4}$ & $49.69 \times 10^{4}$ & $22.11 \times 10^{4}$ & $18.84 \times 10^{4}$ & 8.050 & 0.449 \\
\hline TLC & 28 & $13.25 \times 10^{2}$ & $19.23 \times 10^{2}$ & $18.57 \times 10^{2}$ & $25.81 \times 10^{2}$ & 3.530 & 0.673 \\
\hline
\end{tabular}

[Data represent mean values of 2 birds per replicate groups during 28 days; SEM= Pooled standard error of means].

Carcass yield characteristics of broiler chicken

The results of dressing \%, blood weight \%, drumstick weight $\%$, thigh weight $\%$ and breast weight $\%$ of broiler chicken were influenced significantly $(\mathrm{P}<0.05)$ by dietary treatments

Table 5. Carcass yield traits (\%) of broiler fed on ready-made diet supplemented with probiotics on day 28.

\begin{tabular}{|c|c|c|c|c|c|c|}
\hline & \multicolumn{4}{|c|}{ Treatment } & \multirow[t]{2}{*}{ SEM } & \multirow{2}{*}{$\begin{array}{c}\text { P- } \\
\text { values }\end{array}$} \\
\hline & $\mathrm{D}_{1}$ & $\mathrm{D}_{2}$ & $\mathrm{D}_{3}$ & $\mathrm{D}_{4}$ & & \\
\hline Dressing \% & $61.31^{\mathrm{c}}$ & $63.50^{\mathrm{b}}$ & $65.78^{a}$ & $66.00^{\mathrm{a}}$ & 0.5520 & 0.05 \\
\hline Blood weight & $3.62^{\mathrm{c}}$ & $4 \cdot 31^{\mathrm{b}}$ & $4.92^{a}$ & $5.15^{\mathrm{a}}$ & 0.1390 & 0.05 \\
\hline Drumstick weight & $7 \cdot 76^{c}$ & $8.45^{\mathrm{b}}$ & $8.70^{\mathrm{a}}$ & $9.11^{\mathrm{a}}$ & 0.0874 & 0.05 \\
\hline Thigh weight & $8.75^{\mathrm{c}}$ & $8.97^{b}$ & $9.98^{a}$ & $10.12^{\mathrm{a}}$ & 0.1095 & 0.01 \\
\hline Breast weight & $21.86^{c}$ & $23.70^{\mathrm{b}}$ & $24.86^{a}$ & $25.84^{a}$ & 0.3840 & 0.05 \\
\hline
\end{tabular}

[Data represent mean values of 2 birds per replicate groups during 28 days; a,b,c Means bearing different superscripts in a row are significantly different at ${ }^{* *}=P<0.01$ and ${ }^{*}=P<0.05 ;$ SEM $=$ Pooled standard error of means].

\section{Cost benefit analyses}

The cost benefit of broiler demonstrated that bird on $\mathrm{D}_{4}$ group had received the highest profit $(\mathrm{P}<0.01)$ and lowest production cost (Table 6). The economics of broiler production showed that net profit per bird was significantly higher for probiotics supplemented groups, showing the
(Table 5). Comparatively better dressing \%, blood weight $\%$, drumstick weight $\%$, thigh weight $\%$ and breast weight \% of broiler chicken were found in the birds fed $\mathrm{D}_{4}$ and $\mathrm{D}_{3}$ diet group than that of other treatment group. highest return (Tk.) in $\mathrm{D}_{4}(13.79 \mathrm{Tk})$, followed by $\mathrm{D}_{3}(12.42 \mathrm{Tk})$ and $\mathrm{D}_{2}(8.65 \mathrm{Tk})$. Control group $\left(D_{1}\right)$ had very low profit $4.42 \mathrm{Tk}$. only. The highest return of broilers on supplemental group might be due to lower production cost and increased body weight gain, as is seen in this study.

Table 6. Cost and benefit analysis of broilers fed probiotics on day 28 .

\begin{tabular}{|lcccccc|}
\hline & \multicolumn{9}{c}{ Treatment } & SEM & P - value \\
& $\mathrm{D}_{1}$ & $\mathrm{D}_{2}$ & $\mathrm{D}_{3}$ & $\mathrm{D}_{4}$ & & \\
\hline Live weight (g/b) & $1780^{\mathrm{b}}$ & $1870^{\mathrm{a}}$ & $1890^{\mathrm{a}}$ & $1910^{\mathrm{a}}$ & 6.612 & 0.010 \\
\hline Livability (\%) & 100.00 & 95.83 & 100.00 & 100.00 & 1.042 & 0.441 \\
\hline Feed intake (g/b) & 2250.00 & 2240.00 & 2250.00 & 2250.00 & 6.351 & 0.973 \\
\hline Feed cost (Tk/kg live weight) & 56.88 & 53.92 & 53.57 & 53.00 & - & - \\
\hline Total production cost (Tk/kg live wt.) & $137.58^{\mathrm{a}}$ & $133.35^{\mathrm{a}}$ & $129.58^{\mathrm{b}}$ & $128.21^{\mathrm{b}}$ & 0.264 & 0.010 \\
\hline Market price (Tk/ kg live bird) & 142.00 & 142.00 & 142.00 & 142.00 & - & - \\
\hline Profit (Tk/kg live bird) & $4.42^{\mathrm{c}}$ & $8.65^{\mathrm{b}}$ & $12.42^{\mathrm{a}}$ & $13.79^{\mathrm{a}}$ & 0.063 & 0.010 \\
\hline
\end{tabular}

[Mean values bearing different superscript in a row differ significantly at ${ }^{* *}=P<0.01$ ].

\section{Discussion}

\section{Gross responses of broiler chicken}

It is obvious from the data that the body weight gain of broiler fed probiotics treated group was found to be significantly improved as compared to control group throughout the experiment except for $1^{\text {st }}$ week in this study. The reason for improved body weight of broiler on the supplemental group might be due to the addition of probiotics in the drinking water. The main function of probiotic as feed additives is to 
illustrated that probiotics promote growth performance in the poultry production system compared with non-supplement diet. Midilli and Tuncer (2001) reported significantly improved growth performance in broiler that administered with probiotic orally. Dhande et al. (1993) and Verma (1992) also observed that, probiotic fed broilers had higher body weight and better feed conversion efficiency. The improvement in weekly body weights due to supplementation of probiotic indicated that the inclusion of probiotic beneficially affects the host by improving its intestinal microbial balance as reported by Fuller (1989). It is reported that probiotics have antagonistic effects to various microorganisms proposed in several mechanisms including improvement of gut epithelial barrier function, competition on adhesive receptors, competition on available nutrients, antibacterial effects, degradation and neutralization of toxins and immunomodulatory effect (Abd Al-Fatah, 2020).

No difference was spotted between the treatment of feed intake of broiler chicken fed probiotics supplements in our present study. It denotes that broiler consumed feed uniformly entire the trial period, as no significant differences are found in feed consumption of bird between treatments. The similar trend of feed intake by the broilers on probiotic supplemented diets might be due to feeding same diet and the mode of application of probiotics to the birds. The probiotics was applied the birds via water not with feed, as it were liquid. This mode of application of the probiotics might be a reason for similar feed intake of the broilers. Besides, all birds had a free access to same diet (crumble-pellet) entire the trial period. It was observed that there were no adverse effects of the probiotics on feed consumption, palatability and thereby performance of broiler. Our results might be correlated with some previous studies, which reported that probiotics had no influence on feed consumption, but it can improve growth rate and carcass weight of broiler (Djouvinov et al., 2005a; Djouvinov et al., 2005b). However, on the other hand, our results might contradict with some reports of the previous researchers (Morelli et al., 2003; Sharma et al., 2003), who observed that broiler diet supplemented with probiotics, showed improved feed intake than that of the control. The discrepancy between two studies might be due to the variation in supplying probiotics to birds and sources of probiotics from which these were prepared. In our study, we supplied probiotics through water, whereas they applied probiotics with diet.

It is obvious that the FCR of broiler was improved significantly by probiotics supplements during 128 days. The data of FCR value indicated that birds of $D_{2}, D_{3}$ and $D_{4}$ groups assumed to be more efficient in converting feed to meat than the broilers of control group during 1-28 days. It shows that the birds of these groups assume to be more efficient than that of others, as the broilers of this group had a superior FCR values (1.30;
1.34) than that of control. The results of present study are in agreement with the previous research reported by Dhande et al. (1993) and Verma (1992), who found significant differences in FCR of birds fed probiotics.

Administration of probiotics in diets enhances organic acid production as lactic acid can prevent the gastrointestinal disorders and improve feed efficiency. Therefore, it was observed a significant improvement in body weight gain between 21day and 28 days in broiler (Jin et al., 1998).

\section{Livability, carcass yield trait, caecal microbial population and profitability of broiler fed probiotics}

It is clear from the survivability data that, probiotics had no influence on the livability or mortality of birds. It implies that probiotics do not have any detrimental impact on the viability of broilers. So, it can be applied in the birds without any doubt. The relative weight of dressing $\%$, breast weight $\%$, thigh weight $\%$ and drumstick weight \% of broiler were improved by supplemental group compared to control in this study. The reason for better carcass yield traits of the broilers was probably due to improved body weight gain of birds fed on probiotics diet. The total viable count (TVC) and total Lactobacilli count (TLC) in the caecal digesta of birds had no difference between probiotics supplemented and control groups of broiler. It implies that the microflora found in the caecal digesta was similar in population, though numerically increased microflora (TLC, TVC) was observed in the birds fed probiotics supplemental diets. Caecal microflora of birds has a very little effect on the digestion process of poultry, as the major digestion of broiler takes place by enzymes secreted from the different glands of birds. So, the uniform caecal microbial growth of birds won't play major role on the body growth development of broiler chickens. The probiotics supplementation gave better economic returns, as is seen in our study. An increase in the net profit per bird was found in the treatment groups of $D_{4}$, $\mathrm{D}_{2}, \mathrm{D}_{3}$ with supplementation of probiotics over control group, and it concluded that there was a decreased cost of feed, thereby reduced cost of production, and ultimately it had increased net profit compared to control group.

\section{Conclusion}

An overview of the results obtained in this study revealed that the supplementation of probiotics in the drinking water of broiler enhanced the body weight gain with improved feed efficiency, higher net profit without affecting feed intake. The beneficial microorganisms are also found in high amount in the gut of bird, which could reduce the need of antibiotic and can reduce the ongoing danger of antimicrobial resistance. Therefore, it can be concluded that the optimum outcome could be achieved by probiotic inclusion in the broiler diet. 


\section{References}

Abd Al-Fatah, M. 2020. Probiotic modes of action and its effect on biochemical parameters and growth performance in poultry. Iranian $J$. Appl. Anim. Sci. 10(1): 9-15.

Adil, S., Tufail, B., Gulam, A.B., Masood, S. and Manzoor, R. 2010. Effect of dietary supplementation of organic acids on performance, intestinal histomorphology, and serum biochemistry of broiler chicken. Vet. Med. Int. Article ID Article ID 479485: 1-7. https://doi.org/10.4061/2010/479485

AOAC. 2007. Official Methods of Analysis. $18^{\text {th }}$ ed. Association of Official Analytical Chemists; Arlington VA, USA. pp. 12-56.

Cakir, S., Midilli, M., Erol, E., Simsek, N., Cinar, M. and Altintas, A. 2008. Use of combined probiotic, prebiotic, organic acid and avilamycin in diets of Japanese quails. Rev. Medwell Vet. 159(11): 565-569.

CEC. 2000. Council Regulation 2000/766 concerning certain protection measures with regard to transmissible spongiform encephalopathies and the feeding of animal protein. Official J. Euro. Comm. 43(306): 32-33.

Dhande, V.U., Kukde, R.J., Lende, R.M. and Sarode, D.B. 1993. Effect of giprobiotic on performance of broilers. Poult. Guide. 30: 39-41.

Dibner, J.J. and Richards, J.D. 2005. Antibiotic growth promoters in agriculture: history and mode of action. Poult. Sci. 84(4): 634-643. https://doi.org/10.1093/ps/84.4.634

Djouvinov, D., Stefanov, M., Boicheva, S. and Vlaikova, T. 2005a. Effect of diet formulation on basis of digestible amino acids and supplementation of probiotic on performance of broiler chicks. Trakia J. Sci. 3: 61-69.

Djouvinov, D., Svetlana, B., Tsvetomira, S. and Tatiana, V. 2005b. Effect of feeding lactina probiotic on performance, some blood parameters and caecal microflora of mule ducklings. Trakia J. Sci. 3: 22-28.

Fuller, R. 1989. Probiotics in man and animals. $J$. Appl. Bacteriol. 66: 365-378. https://doi.org/10.1111/j.1365-2672.1989.tbo5105.x

Gunal, M., Yayli, G., Kaya, O., Karahan, N. and Sulak, O. 2006. The effects of antibiotic growth promoter, probiotic or organic acid supplementation on performance, intestinal micro flora and tissue of broilers. Int. $J$. Poult. Sci. 5: 149-155. https://doi.org/10.3923/ijps.2006.149.155

ISO. 1995. Guide to the Expression of Uncertainty in Measurement. Geneva, Switzerland. p.10.

Jin, L.Z., Ho, Y.W., Abdullah, N. and Jalaludin, S. 1998. Growth performance, intestinal microbial populations, and serum cholesterol of broilers fed diets containing Lactobacillus cultures. Poult. Sci. 77: 12591265. https://doi.org/10.1093/ps/77.9.1259

Kalavathy, R., Abdullah, N., Jalaludin, S. and Ho, Y.W. 2003. Effects of Lactobacillus cultures on growth performance, abdominal fat deposition, serum lipids and weight of organs of broiler chickens. Br. Poult. Sci. 44: 139-144.

https://doi.org/10.1080/0007166031000085445 Midilli, M. and Tuncer, S.D. 2001. The effects of enzyme and probiotic supplementation to diets on broiler performance. Turkish J. Vet. Anim. Sci. 12: 895-903.

Minitab . 2000. Minitab Statistical Software User Guide 2: Data Analysis \& Quality Tools. Minitab Inc., State College, P.A. USA. p.27.

Morelli, L., Zonenschain, D., Callegari, M.L., Grossi, E., Maisano, F. and Fusillo, M. 2003. Assessment of a new synbiotic preparation in healthy volunteers: survival, persistence of probiotic strains and its effect on the indigenous flora. Nutr. J. 2: 11. https://doi.org/10.1186/1475-2891-2-11

Mountzouris, K.C., Tsitrsikos, P., Palamidi, I. Arvaniti, A., Mohnl, M., Schatzmayr, G. and Fegeros, K. 2010. Effects of probiotic inclusion levels in broiler nutrition on growth performance, nutrient digestibility, plasma immunoglobulins, and cecal microflora composition. Poult. Sci. 89: 5867. https://doi.org/10.3382/ps.2009-00308

Ohimain, E.I. and Ofongo, R.T.S. 2012. The effect of probiotic and prebiotic feed supplementation on chicken health and gut microflora: A Review. Int. J. Anim. Vet. Adv. 4: $135-143$.

Patterson, J.A. and Burkholder, K.M. 2003. Application of prebiotics and probiotics in poultry production. Poult. Sci. 82: 627-631. https://doi.org/10.1093/ps/82.4.627

Sharma, K.S., Gupta, M., Meema, K. and Singh, G. 2003. Biological performance of commercial broiler fed diets supplemented with microbial strains isolated from indigenous sources. pp. 112-122. In: proceeding $21^{\text {st }}$ Conference of Indian Poultry Science Association and National Symposium on diversification of Poultry for Nutritional Security, Izatnagar, India, March 27-28, 2003.

Shim, Y.H., Shinde, P.L., Choi, J.Y., Kim, J.S., Seo, D.K., Pak, J.I., Chae, B.J. and Kwon, I.K. 2010. Evaluation of multimicrobial probiotics produced by submerged liquid and solid substrate fermentation methods in broilers. Asian-Aust. J. Anim. Sci. 23: 521529. https://doi.org/10.5713/ajas.2010.90446

Verma, S.V.S. 1992. Prospects of improving nutritive value of poultry feeds through biotechnology. Poult. Guide. 29: 37-39.

Wallace, R.J., Oleszek, W., Franz, C., Hahn, I., Baser, K.H.C., Mathe, A. and Teichmann, K. 2010. Dietary plant bioactives for poultry health and productivity. Br. Pout. Sci. 51: 461-487.

https://doi.org/10.1080/00071668.2010.506908

Wiseman, J. (Ed.). 1987. Feeding of Nonruminant Livestock. Elsevier. pp. 8-13. 